\title{
Cytogenotoxicity screening of source water, wastewater and treated water of drinking water treatment plants using two in vivo test systems: Allium cepa root based and Nile tilapia erythrocyte based tests
}

Chamini K. Hemachandra ${ }^{\mathrm{a} 1}$ and Asoka Pathiratne ${ }^{\mathrm{a}}$

${ }^{a}$ Department of Zoology and Environmental Management, University of Kelaniya, Kelaniya, GQ 11600, Sri Lanka.

${ }^{1}$ Present address: Industrial Technology Institute, Colombo 7, Sri Lanka

Correspondence to: Professor Asoka Pathiratne, Tel: + 9411 2903393, Fax: + 9411 2914479, E- mail: asoka@kln.ac.lk 


\begin{abstract}
Biological effect directed in vivo tests with model organisms are useful in assessing potential health risks associated with chemical contaminations in surface waters. This study examined the applicability of two in vivo test systems viz. plant, Allium cepa root based tests and fish, Oreochromis niloticus erythrocyte based tests for screening cytogenotoxic potential of raw source water, water treatment waste (effluents) and treated water of drinking water treatment plants (DWTPs) using two DWTPs associated with a major river in Sri Lanka. Measured physico-chemical parameters of the raw water, effluents and treated water samples complied with the respective Sri Lankan standards. In the in vivo tests, raw water induced statistically significant root growth retardation, mitodepression and chromosomal abnormalities in the root meristem of the plant and micronuclei/nuclear buds evolution and genetic damage (as reflected by comet scores) in the erythrocytes of the fish compared to the aged tap water controls signifying greater genotoxicity of the source water especially in the dry period. The effluents provoked relatively high cytogenotoxic effects on both test systems but the toxicity in most cases was considerably reduced to the raw water level with the effluent dilution (1:8). In vivo tests indicated reduction of cytogenotoxic potential in the tested drinking water samples. The results support the potential applications of practically feasible in vivo biological test systems such as $A$. cepa root based tests and the fish erythrocyte based tests as complementary tools for screening cytogenotoxicity potential of the source water and water treatment waste reaching downstream of aquatic ecosystems and for evaluating cytogenotoxicity eliminating efficacy of the DWTPs in different seasons in view of human and ecological safety.
\end{abstract}

Key words: drinking water; source water; bioassay; cytotoxicity; genotoxicity; Kelani River 


\section{Introduction}

Pollution of inland surface waters by anthropogenic sources such as industrial effluents, agricultural runoff and domestic/municipal waste with complex mixtures of unknown and known toxic chemicals has become a critical issue worldwide. 'Emerging contaminants' such as pharmaceuticals and personal care products are increasingly been detected in surface waters and concerns have been raised on effective elimination of such contaminants from drinking water treatment plants (Padhye et al., 2014; McKie et al., 2016). Although it is essential to disinfect drinking water for prevention of the spread of diseases caused by water borne pathogens, disinfection by-products can be formed during drinking water production, when disinfectants react with naturally occurring organic matter and anthropogenic contaminants (Hua and Reckhow, 2007; Serrano et al., 2015). These disinfection by-products are potentially genotoxic and carcinogenic (Richardson et al., 2007). Water treatment processes that are used to produce safe drinking water, generate waste with a heterogeneous mixture of residual products depending on the contaminants in the untreated source water, chemicals used for water purification and types of unit operations used (Ippolito et al., 2011). Indiscriminate discharge of such water treatment waste into inland watercourse may pose additional health risks to biota.

Potential hazards of chemical contaminations associated with source waters are routinely monitored focusing on conventional physico-chemical analysis. These waters may contain undetected/unknown micropollutants (Luo et al., 2014) which may be biologically active even at trace concentrations. Potential interactive toxicity of different contaminant mixtures in these waters can only be evaluated by 'biological effect directed tests'. Of the chronic toxic effects induced by chemicals, main concerns are the mutagenic hazards which could lead to ecological health risks and serious human afflictions. In a review of mutagenic contaminations in rivers, 
importance of genotoxicity assays in water quality monitoring programmes has been emphasized (Ohe et al. 2004). Different in vitro models (such as bacteria and cell cultures) with extracts or concentrates of the water samples have been commonly explored for detection of genotoxic contaminants in surface waters and/or drinking water (Maffei et al., 2009, Žegura et al., 2009, Shi et al., 2015, Zeng et al., 2015). Combined use of appropriate in vivo models such as plants and fishes with direct exposure to the water samples would be more applicable for assessing genotoxic potential of contaminated waters to higher levels of biological organization. The plant, Allium cepa (common onion) root based tests are sensitive and economical bioassays for evaluating cytotoxicity and genotoxicity of environmental samples. The test results show good correlations with mammalian test systems (Leme and Marin-Morales, 2009). Oreochromis niloticus (Nile tilapia) has been used as the bioindicator organism for genotoxicity evaluations of surface waters based on in vivo erythrocytic micronucleus tests or/and erythrocyte based comet assay (Osman et al., 2012, Fuzinatto et al., 2013). This tropical fish species is a practically feasible aquatic model especially in developing countries for screening genotoxic potential of surface water and treated water prior to distribution for drinking purposes.

The present study explored for the first time potential applicability of combination of two in vivo test systems viz. the plant $A$. cepa root based tests and the fish, $O$. niloticus erythrocyte based tests along with conventional physico-chemical analysis for screening cytogenotoxic potential of raw surface waters, water treatment waste and treated waters using different waters of drinking water treatment plants associated with a major river (Kelani River) in Sri Lanka. Kelani River is polluted with various land based sources including industrial effluents, agricultural runoff, domestic and urban waste (Illeperuma, 2000) which may contain diverse chemical mixtures with high cytogenotoxic potential. Nevertheless, drinking water treatment 
plants (DWTPs) are located at different points along the river basin for water purification in order to provide drinking water to the most of the inhabitants in the urbanized cities and townships located in the watershed.

\section{Material and methods}

\subsection{Drinking water treatment plants}

Two large scale drinking water treatment plants (DWTP1 and DWTP2) which supply drinking water for several highly populated cities were selected in this study. Both DWTPs use the conventional drinking water treatment process for purifying surface waters of Kelani River. The water treatment process includes aeration, flocculation (with $\mathrm{Al}_{2}\left(\mathrm{SO}_{4}\right)_{3}$ and salts of $\mathrm{Fe}$ ), sedimentation, sand filtration and post-chlorination (with chlorine gas) steps. Final pH of the water is maintained around 7 (by adding $\mathrm{Ca}(\mathrm{OH})_{2}$ if required) and the resulting water is stored in sumps to be distributed to the general public (Personal communication, Chemists of the DWTPs). The quality of raw water and drinking water is monitored according to the national standards (SLSI, 1985; 2013). Both DWTPs discharge the water treatment waste (effluents) into the downstream of the river. The sludge retained after the water treatment at the DWTP2 is eventually removed to an abandoned land. The effluents are discharged at substantially distant points from the raw water input sites. The DWTP effluents discharged into inland surface waters are expected to be diluted by at least 8 fold with the clean receiving water (Anonymous, 2008).

\subsection{Water and effluent collection}


The raw surface water at the intake sites and effluents at the wastewater discharge outfalls were collected in three sampling events covering the rainfall pattern: wet periods with high rainfall (DWTP1: $13^{\text {th }}$ December 2012, $23^{\text {rd }}$ October 2013; DWTP2: $13^{\text {th }}$ December 2012, $18^{\text {th }}$ September 2013 ) and dry periods with low rainfall (DWTP1:19 ${ }^{\text {th }}$ June 2013; DWTP2: $17^{\text {th }}$ April 2013). In each sampling event, composite raw water samples were obtained by mixing sub samples from a particular site. Composite effluent samples were also obtained from the discharge points. The raw water/effluent samples were transported to the laboratory under chilled condition after in-situ measurement of selected physico-chemical parameters. Subsamples of water and effluents were preserved following standard methods (Eaton et al., 2005) for measurements of selected physico-chemical parameters. Biological tests were started on the same day of the sampling.

Water samples covering different water treatment processes in each DWTP viz. raw water, filtered water, post-chlorination water and finished water samples distributed for general public (from a tap located at $>1 \mathrm{~km}$ distant point) were collected in a relatively low rainfall period (DWTP1: $20^{\text {th }}$ August 2014 and DWTP2: $23^{\text {rd }}$ July 2014). For each category of water, composite samples were obtained and selected physico-chemical parameters were measured insitu and processed in the laboratory for further characterizations and biological tests.

\subsection{Measuring physico-chemical parameters}

Temperature, $\mathrm{pH}$, conductivity, salinity and total dissolved solids (TDS) in water and effluent samples were measured in-situ (MPS-556 water quality checker, Yellow Springs Instrument Company, USA). Dissolved oxygen (DO), biochemical oxygen demand for 5 days (BOD5), and chemical oxygen demand (COD) in the samples were determined using standard 
methods(Eaton et al., 2005). Water and effluent samples were analyzed for selected heavy metals $(\mathrm{Cd}, \mathrm{Cr}, \mathrm{Cu}, \mathrm{Pb}$ and $\mathrm{Zn})$ using atomic absorption spectrometry (Analytik Jena model: novAA 400P atomic absorption spectrometer equipped with a graphite furnace and auto sampler) following Eaton et al. (2005). The concentration that corresponds to the sum of the mean and 10 times the standard deviation of seven independent measurements of the digested medium for each metal was used as the limit of quantification (LOQ) for the respective metal. For color analysis (Anonymous, 2008), the water/effluent samples were filtered and absorbance values were recorded at stipulated wavelengths $(436 \mathrm{~nm}$ : for Yellow color, $525 \mathrm{~nm}$ : for Red color and $620 \mathrm{~nm}$ : for Blue color) with distilled water as the blank correction using UV-visible scanning spectrophotometer (GBC Cintra 10e, Australia) for determination of respective spectral absorption coefficients.

\subsection{A. cepa root based tests}

Bioassays were conducted with commercially available $A$. cepa bulbs (7-10 g in weight) under laboratory conditions in the dark at $25-27{ }^{\circ} \mathrm{C}$ following the procedure described previously (Pathiratne et al., 2015). Samples of raw water, undiluted effluents and diluted (1:8) effluents from the respective DWTPs were used as the exposure media ( $\mathrm{n}=10$ onion bulbs per medium). Raw source water was used as the effluent dilution medium to simulate the natural dilution with the surface water. Unless otherwise stated, aged tap water (treated drinking water from Kelani River) was used as the control medium after leaving the water under continuous aeration at 27$30{ }^{0} \mathrm{C}$ for three days to release residual chlorine. All exposure media were renewed daily. After two days, 10 root tips from each onion bulb from randomly selected five onion bulbs from each exposure were processed for cytogenotoxicity evaluations. The mitotic index was calculated as 
percentage of cells undergoing mitosis in comparison to the total cells examined per each bulb. Different types of chromosomal abnormalities were categorized based on the descriptions given earlier (Leme and Marin-Morales, 2009, Pathiratne et al., 2015). Chromosomal abnormalities were presented as total number of abnormalities in 100 dividing cells (excluding prophase) per onion bulb. Frequencies of micronucleated cells and the cells with nuclear buds were estimated with respect to 1000 interphase cells per each bulb. For testing root growth response, a separate set of $A$. cepa bulbs were submerged in different exposure media (raw water, undiluted effluents, 1:8 diluted effluents and aged tap water) continuously for seven days with daily renewal of exposure media as described by Hemachandra and Pathiratne (2016).

A separate study was conducted by exposing A. cepa bulbs to water samples from different treatment steps in each DWTP (Section 2.2) along with negative controls and positive controls following the same bioassay procedures. In this study, A. cepa bulbs concurrently exposed to portable drinking water (source: a natural spring of Katooloya estate, Thawalantenna, Kandy, Sri Lanka) was used as the negative control whereas the bulbs exposed to a known mutagen, Ethyl methane sulphonate (EMS, $\geq 98 \%$ purity from Sigma-Aldrich) at $10 \mathrm{mg} \mathrm{L}^{-1}$ in portable drinking water was used as the positive control.

\subsection{O. niloticus erythrocyte based tests}

Samples of Nile tilapia, O. niloticus were obtained from a fish breeding station of National Aquaculture Development Authority of Sri Lanka. Fish were acclimated to the laboratory conditions for three weeks. Exposure of fish $(8-10 \mathrm{~cm}$ in total length, $\mathrm{n}=5$ fish per 15 L exposure medium in glass tanks) to raw water, undiluted and 1:8 diluted effluents from the respective DWTPs and the aged tap water (control) was carried out under continuous aeration 
with renewal of exposure media every other day as described by Hemachandra and Pathiratne (2016). In a separate study, acclimated fish were exposed to water samples from different water purification steps of respective DWTPs (Section 2.2) along with the negative controls and positive controls following the same procedure. The fish exposed to the portable drinking water (Section 2.4) was used as the negative control whereas the fish exposed to a known genotoxicant, potassium dichromate $\left(\mathrm{K}_{2} \mathrm{Cr}_{2} \mathrm{O}_{7}, \geq 99 \%\right.$ purity, Normapur, Belgium) at $2.5 \mathrm{mg} \mathrm{L}^{-1}$ in the portable drinking water $\left(8.5 \mu \mathrm{mol} \mathrm{L}{ }^{-1}\right.$ as $\left.\mathrm{Cr}^{6+}\right)$ was used as the positive control. The fish were not fed during the exposure period. During the exposure, measured temperature, $\mathrm{pH}$, and DO levels of the exposure media were within the favorable limits for fish. After five days, the fish were anesthetized (with benzocaine hydrochloride $0.7 \mathrm{~g} \mathrm{~L}^{-1}$ ) and blood was drawn from the caudal vein for cyto-genotoxicity assessments. International ethical guidelines in relation to animal care and experimentations were followed in the fish bioassays.

For erythrocytic abnormalities test, a thin blood smear from each fish was prepared and fixed with absolute methanol and stained with 5\% Giemsa. The coded slides were scored blindly using a binocular light microscope. A minimum of 1000 mature erythrocytes per slide were observed under oil immersion (1000x). Micronuclei and nuclear buds were identified as described earlier (Al-Sabti and Metcalfe, 1995; Hemachandra and Pathiratne, 2016). The results are expressed as the \%o of the cells with the respective abnormality from a total of 1000 erythrocytes.

Alkaline comet assay was conducted for fish blood as described previously (Hemachandra and Pathiratne, 2016). Briefly, heparinized blood diluted with phosphate buffered saline was added to $0.5 \%(\mathrm{w} / \mathrm{v})$ low melting agarose (LMA) maintained at $37{ }^{0} \mathrm{C}$. The mixture was smeared onto an air dried frosted microscope slide previously coated with $1 \%$ (w/v) normal 
melting agarose and a clean cover slip was used to make a thin film of LMA and erythrocytes on the coated slides. After solidification, the slides were coated again with a layer of $0.5 \%$ LMA and allowed to solidify before the cover slips were gently removed. The slides were immersed in freshly prepared cold lysing buffer ( $\mathrm{pH} 10)$ and kept overnight under $4{ }^{0} \mathrm{C}$. On the following day, the slides were washed with chilled distilled water and incubated with electrophoresis buffer ( $\mathrm{pH}$ $\geq 13$ ) in a Comet assay electrophoresis tank (Consort, Belgium). Following electrophoresis, the slides were flushed with $0.4 \mathrm{M}$ Tris buffer ( $\mathrm{pH}$ 7.5) for 3 times for neutralization. Finally, the slides were stained with ethidium bromide and the comet images were observed at $\mathrm{x} 400$ magnification using the fluorescence microscope (Olympus BX43) linked to a digital video camera (Olympus DP 73, Japan) interfaced with a computer. A total of hundred nucleoids were analyzed from each fish using a visual classification method (Collins et al., 1995). In this method, five classes (0-4) are used to characterize DNA damage based on migration of DNA fragments from the nucleoid. Total comet score was estimated as the cumulative value of all class specific scores.

\subsection{Statistical analysis}

The data are presented as mean \pm SEM $(n=5)$. For each DWTP, the data with respect to a particular sampling event were compared using One way analysis of variance (ANOVA) followed by Tukey's pair wise comparison test. Statistical significance was set at $\mathrm{P}<0.05$. The proportional data were subjected to arcsine transformations before statistical analysis (Zar, 1999). 


\section{Results and discussion}

\section{1 Quality of raw water, effluents and treated waters based on physico-chemical analysis}

The measured physico-chemical parameters of raw water (surface water of Kelani River) and effluent samples of the DWTPs are presented in Table 1. Most of the measured parameters in the raw water samples complied with the available Sri Lankan tolerance limits for inland surface waters for use as raw water for public water supply (SLSI, 1985). However, chemical contamination status of intake raw water samples cannot be completely assessed without comprehensive chemical characterizations. Considering land based pollution sources of the river (Illeperuma, 2000), these raw water samples might contain a complex mixture of chemicals which could induce cytotoxic and genotoxic effects. Potential cytogenotoxic hazards posed by treated effluents of two textile industries discharged into the Kelani River have been reported recently (Hemachandra and Pathiratne, 2016). Depending on the raw water source and chemicals used for water purification, heterogeneous mixture of chemicals may be present in the generated waste (Ippolito et al., 2011) by the two DWTPs. Except the color measurements in the DWTP1 effluent in a wet period, all other measured parameters including the five heavy metals (Table 1) were within the specified tolerance limits for discharge of industrial effluents into the inland surface waters of Sri Lanka (Anonymous 2008). High levels of aluminum and iron have been reported earlier in the water treatment effluents (Pathiratne et al., 2015). These metals may have originated from the flocculation step of the water treatment process. The measured physicochemical parameters of water collected from different stages of the water treatment processes of the two DWTPs and the portable drinking water (Tables 1,2) complied with the national tolerance limits for the intake source water (SLSI, 1985), national drinking water quality 
standards (SLSI, 2013) and available WHO guidelines for drinking water quality (WHO, 2011). Since, chemical characterization of these water samples is not exhaustive, it is difficult to comment on their potential hazards merely based on chemical contamination status. There can be complex mixtures of chemicals at trace levels which may induce cytogenotoxic impacts.

\subsection{Cytogenotoxicity screening of raw water and effluents}

\subsubsection{A. cepa root based tests}

A. cepa test system can be considered as one of the most efficient, practically feasible and low cost methods in assessing toxic/cytotoxic and genotoxic effects of contaminant mixtures in the aquatic environments (Leme and Marin-Morales, 2009). In the A. cepa test system, root growth retardation and mitotic index depression in the root tip cells indicate toxicity/cytotoxicity whereas induction of chromosomal abnormalities, micronuclei and nuclear buds in the root cells indicate genotoxicity. Occurrence of micronuclei can also be used to verify mutagenicity (Leme and Marin-Morales, 2009). A. cepa bioassay has been used effectively for toxicity/genotoxicity evaluations of diverse groups of environmental chemicals including heavy metals (i.e. Hemachandra and Pathiratne, 2015), disinfection by-products (Monarca et al., 2005) and unregulated contaminants of emerging concern (Herrero et al., 2012). In the present study, mitotic indices were significantly lower in the A. cepa root tips (Fig. 1) exposed to intake source water of Kelani River and the effluents of the DWTPs (undiluted and 1:8 diluted) compared to those exposed to the aged tap water (control). The undiluted effluents exhibited the greatest mito-depressive effect in most cases implying relatively high cytotoxic contaminations. Mitotic indices of the roots exposed to raw water and the diluted effluents of the DWTPs were not significantly different from each other in most cases (except in the DWTP2 in wet period 2) 
implying adequacy of the 1:8 dilution in general to decrease mito-depressive effects of the water treatment waste discharged into the downstream. Mito-depression can affect the growth and development of exposed organisms (Leme and Marin-Morales, 2009). Root lengths of the onion bulbs exposed to raw water and effluents of the DWTPs (Fig. 1) were significantly lower than those of the aged tap water (control). In most cases, prominent root growth retardation effect was exhibited by the undiluted effluents compared to the diluted effluents. Nevertheless, root growth values of A. cepa exposed to the diluted effluents were significantly lower than that of the raw waters of both DWTPs in the dry periods, indicating insufficiency of the 1:8 dilution to restrict root growth retardation effect of the effluents in the dry periods. Based on the mito-depressive and root growth retardation effects on the plant model, A. cepa, the cytotoxic potential of the samples decreased in the following order: undiluted wastewater $>$ diluted wastewater $\geq$ raw water > aged tap water.

Of all the samples examined, the highest occurrence of chromosomal abnormalities in $A$. cepa (Fig. 2) was recorded in the root tip cells exposed to the undiluted effluents indicating greater genotoxic contaminations in the wastewaters. Chromosomal abnormalities of the cells exposed to the diluted effluents (1:8) were not significantly different from those of raw waters in all sampling events and from the aged tap water (control) in most sampling events. Chromosomal abnormalities in the cells exposed to the raw waters sampled during the dry period from both DWTPs were significantly higher than those of the tap water (control) indicating greater genotoxic potential of -raw waters in the dry periods. Based on the chromosomal abnormalities test of A. cepa, genotoxic potential of the samples decreased in the following pattern: undiluted wastewater $>$ diluted wastewater $\approx$ raw water $\geq$ aged tap water. 
Following exposure to clastogenic and aneugenic substances, micronuclei may arise in the dividing cells as a result of chromosomal breakage, alteration of chromosome structure or alteration of chromosomal distribution in the cell division process whereas nuclear buds may arise as a result of the elimination of exceeding genetic material derived from the polyploidization process (Heddle et al., 1991). In the present study, micronuclei or nuclear buds were not seen in the A. cepa root tip cells exposed to the aged tap water control. Micronucleated cells were occasionally present in the root tips exposed to the undiluted effluents (DWTP1: 0.3 $\%$ in dry period; DWTP2: $1.5 \%$ in wet period 2). Nuclear buds were noted in the root tip cells exposed to the undiluted effluents from DWTP 2 in all sampling events (1.2-3.1\%) and from DWTP in wet period $2(8.2 \%)$. Occasional induction of nuclear buds was also noted with the diluted effluents (2.1\%o in wet period 1 from DWTP1; $2.5 \%$ in wet period 2 from DWTP2) and raw waters $(0.4 \%$ in wet period 2 from DWTP $1 ; 0.6 \%$ in the dry period and wet period 2 from DWTP2). Even though a consistent pattern was not evident, evolution of micronuclei and nuclear buds in the dividing cells exposed to raw water and effluent samples may indicate presence of genotoxic/mutagenic contaminants. Differences between response patterns of micronuclei/nuclear buds tests and chromosomal abnormalities test could be due to the time lags associated with the different mechanisms of these genotoxicity tests. A. cepa bioassay has been used earlier for cytotoxicity/genotoxicity evaluation of surface water (Vujošević et al., 2008, Dusman et al., 2014, Kannangara and Pathiratne, 2015) and drinking water (Abda et al., 2015). The present study extended the application of A. cepa bioassay in cytogenotoxicity assessments of the drinking water treatment waste under different climatic periods.

\subsubsection{O. niloticus erythrocyte based tests}


Frequencies of micronuclei and nuclear buds in the erythrocytes of $O$. niloticus (Fig. 3) exposed to the aged tap water samples were relatively low. Raw water samples of the DWTPs especially in the dry period caused significantly greater induction of erythrocytic micronuclei and nuclear buds compared to the aged tap water. Induction of erythrocytic micronuclei has also been reported in $O$. niloticus exposed to waters from a river in Brazil (Fuzinatto et al., 2013). The highest frequencies of erythrocytic micronuclei and nuclear buds were found in the fish exposed to the effluents in most cases indicating greater genotoxicity/mutagenicity induced by the contaminants in the water treatment waste. With the 1:8 dilution, occurrence of micronuclei and nuclear buds was significantly reduced. Based on fish erythrocytic micronuclei and nuclear buds tests, genotoxic/mutagenic potential of the samples followed the decreasing order: undiluted wastewater $>$ diluted wastewater $\approx$ raw water $\geq$ aged tap water. This pattern corresponds with the results of chromosomal abnormality tests conducted with A. cepa.

Alkaline in vivo comet assay can be applied for the detection of DNA strand breaks in aquatic species following exposure to genotoxins (Frenzilli et al., 2009). O. niloticus erythrocyte based comet assay has been effectively used for genotoxicity assessments of surface waters (Osman et al., 2012). The total comet scores which reflect the DNA damage in the erythrocytes of $O$. niloticus exposed to aged tap water, raw water and effluents of the DWTPs are presented in the Fig. 4. The total comet scores of the erythrocytes of the fish exposed to the aged tap water samples (control) were relatively low in all cases. The fish exposed to raw water samples of both DWTPs exhibited significantly higher total comet scores compared to the tap water (control) indicating greater DNA damaging effect of the raw waters. The effluents (diluted and undiluted) from both DWTPs induced significantly higher total comet scores than that of the aged tap water (control). Highest total comet scores were shown by the fish exposed to the undiluted effluents in 
all cases. Total comet scores with respect to the diluted effluents were not significantly different from those of the corresponding raw water samples indicating adequacy of the 1:8 dilution of the effluents to restrict the DNA damage to the raw water level. Based on fish erythrocytic comet assay, genotoxic potential of the tested samples followed the decreasing order: undiluted wastewater $>$ diluted wastewater $\approx$ raw water $>$ aged tap water. In general, raw water/wastewater caused induction of numerically greater total comet scores in the dry period compared to the wet period.

\subsubsection{Combining physico-chemical analysis with cytogenotoxicity tests}

Even though, measured physico-chemical parameters of the raw water and effluents of the two DWTPs and tap water complied with the respective Sri Lankan standards, raw water of both DWTPs caused statistically significant root growth retardation, mitodepression and increase in chromosomal abnormalities in root meristem of the plant, A. cepa and induction of erythrocytic micronuclei/nuclear buds and comet scores of the fish, O. niloticus in comparison to the aged tap water (control) in most cases signifying cytogenotoxic potential of the source waters. Greater genotoxic potential exhibited by the raw water in the dry periods may be associated with concentrating effect of the pollutants in the river water with low flow rates and high evapo-transpiration under tropical dry weather conditions. In the wet periods, high flow rates associated with the rain water could have diluted the genotoxic pollutant loads in the raw water. Established Sri Lankan tolerance limits for discharge of industrial effluents into inland surface waters are based on the expected dilution of the effluent by at least eight volumes of clean receiving water (Anonymous 2008). The water treatment effluents generated by both DWTPs frequently induced relatively high cytogenotoxic effects on both test systems but 
genotoxicity has been considerably reduced to the raw water level in most cases with the effluent dilution (1:8). Yet, 1:8 dilution of the effluents sampled in the dry periods was not adequate to restrict the root growth retardation effect to raw water level. The results indicate inadequacy of the expected effluent dilution in the dry weather conditions to curtail potential toxic effects under long term exposure. Greater cytotoxic and genotoxic effects observed in the raw water and wastewater samples of DWTPs can be associated with the interactive effects of diverse contaminant mixtures. A comprehensive chemical analysis in the river water focusing on a range of micropollutants is warranted covering different climatic seasons especially in the sites where raw water is extracted for drinking purposes in order to identify the specific components which could potentially contribute to elicit cytogenotoxicity.

\subsection{Cytogenotoxicity screening at different water treatment stages}

\subsubsection{A. cepa root based tests}

A. cepa roots exposed to EMS (positive control) showed significant decrease in mitotic indices, induction of chromosomal abnormalities, micronuclei and nuclear buds in the root tip cells (Table 3) compared to those exposed to the portable drinking water (negative control) confirming the cytogenotoxic/mutagenic effects of the known mutagen. The roots exposed to raw waters of both DWTPs showed statistically significant mitodepression and decreased root growth in comparison to the negative control confirming cytotoxic properties of intake source waters (Table 3). Root growth retardation effect of the raw water has been reduced to some extent in the distribution water samples. Occurrence of chromosomal abnormalities was significantly higher in the cells exposed to raw waters, filtered waters, chlorinated waters and distribution waters of both DWTPs compared to the negative control. Highest number of 
chromosomal abnormalities were noted in the cells exposed to chlorinated waters. Micronuclei and nuclear buds were observed in the root tip cells exposed to the raw waters of both DWTPs confirming potential genotoxicity/mutagenicity (Table 3). Nuclear buds were also observed in the cells exposed to chlorinated waters from both DWTPs. As shown by mitotic index test and root growth tests, cytotoxic effects of the raw waters have been reduced to some extent in the distribution samples but chromosomal abnormalities test implies that genotoxic potential has not been completely eliminated with the water treatment.

\subsubsection{O. niloticus erythrocyte based tests}

Frequencies of micronuclei, nuclear buds and total comet score (Table 4) were greater in the erythrocytes of $O$. niloticus exposed to positive control, $\mathrm{K}_{2} \mathrm{Cr}_{2} \mathrm{O}_{7}$ compared to the negative

control (portable drinking water) confirming genotoxicity/mutagenicity of $\mathrm{Cr}^{6+}$. Significantly higher frequencies of micronuclei and nuclear buds were found in the erythrocytes of the fish exposed to the raw water of both DWTPs (Table 4) compared with the negative control signifying potential genotoxicity/mutagenicity of the source water. The erythrocytes of the fish exposed to the chlorinated water from the DWTP2 also showed significantly higher occurrence of micronuclei and nuclear buds. The erythrocytes of fish exposed to raw water, filtered water and chlorinated water samples collected from DWTPs showed significantly higher total comet scores than that of the negative control. In both DWTPs, distribution water samples did not show evidence of much genotoxic potential in the fish erythrocyte based bioassays.

\subsubsection{Combining physico-chemical analysis and cytogenotoxicity tests}


The measured physico-chemical parameters of water samples collected from the two DWTPs and the portable drinking water were within the respective national standards (SLSI, 1985; 2013) and WHO guidelines for drinking water quality (WHO, 2011). Since, chemical characterization of these water samples is not comprehensive, it is difficult to comment on the actual chemical contamination status as there can be a complex mixture of chemicals at trace levels which may cause cytogenotoxic impacts. Nevertheless, both in vivo test systems (A. cepa root based tests and fish erythrocyte based tests) confirm the cytogenotoxicity of source waters of both DWTPs. As shown by mitotic index and root growth tests of A. cepa, cytotoxicity associated with raw waters has been reduced to some extent in the distribution water samples. Disinfection by-products which could be formed by chlorination (Hua and Reckhow, 2007) may have also contributed to enhance genotoxic effect of the chlorinated water samples. However information on the levels of chlorine and its by-products in the treated waters used in this study are not available to support the findings. Chlorinated disinfectants, seem to represent the major source of clastogenic/aneugenic by-products following superficial water disinfection for potabilization, as assessed by the micronucleus assay and comet assay of the fish, Cyprinus carpio (Buschini et al., 2004). O. niloticus erythrocytes based comet assay indicated that genotoxic potential of the chlorinated water had been significantly reduced in the distribution water. Chromosomal abnormalities test of $A$. серa implies that genotoxic potential has not been completely eliminated in the distribution waters with the water treatment. Different responses could be due to the time lags associated with the different mechanisms of these genotoxicity tests in addition to the inherent species sensitivity to different exposure conditions. Hence it is important to use battery of tests in screening cytogenotoxicity of these waters. This study based on limited sampling events, indicates that cytogenotoxic potential in the raw water had been 
considerably reduced with the water treatment process by both DWTPs. Further studies are warranted in order to assess the efficacy of the water treatment process in eliminating the cytogenotoxic potential of the drinking waters in different climatic conditions as high genotoxic potential raw water samples was revealed in the dry periods.

\section{Conclusions}

- Applicability of combination of in vivo plant and fish based test systems (A. cepa rootbased and $O$. niloticus erythrocyte-based tests) along with physico-chemical analysis for cytogenotoxic assessments of source water, wastewater and treated water of conventional drinking water treatment plants was explored covering different climatic periods. Both test systems revealed greater cytotoxic potential of the raw intake water in dry and wet periods and elevated genotoxic potential in the dry period. Water treatment effluents provoked relatively high cytotoxic and genotoxic effects on both test systems but the toxicity in most cases was considerably reduced to raw water level with the 1:8 dilution. Overall results indicate that the cytogenotoxic potential has been reduced but not eliminated in the treated drinking water samples.

- Considering human and ecological safety, in vivo test systems such as A. cepa root based tests and the fish erythrocyte based tests appear to be promising complementary tools for cytogenotoxicity screening of the surface water and water treatment effluents and evaluating cytogenotoxicity eliminating efficacy of the drinking water treatment plants in 
different climatic periods. In developing countries where comprehensive water quality monitoring programmes covering a wide range of micropollutants are not carried out due to resource limitations, these in vivo test systems could be applied as practically feasible complementary tools for screening cytogenotoxicity potential in combination with conventional physico-chemical analysis.

\section{Acknowledgements}

This research was funded by the National Research Council of Sri Lanka (grant number: 1111) and the National Science Foundation of Sri Lanka (grant number: RG/2011/EQ/16). We would like to thank management of the DWTPs for providing access to the sites.

\section{References}

Abda, A., Benouareth, D.E., Tabet, M., Liman, R., Konuk, M., Khallef, M., Taher, A., 2015. Mutagenicity and genotoxicity of drinking water in Guelma region, Algeria. Environmental Monitoring and Assessment 187:21. doi:10.1007/s10661-014-4223-6

Al-Sabti, K., Metcalfe, C.D., 1995. Fish micronuclei for assessing genotoxicity in water. Mutation Research 343(2-3), 121-135.

Anonymous, 2008. The Gazette of the Democratic Socialistic Republic of Sri Lanka (Extraordinary) 1534/18: National Environmental (Protection and Quality) Regulations, No. 1 of 2008. 
Buschini, A., Martino, A., Gustavino, B., Monfrinotti, M., Poli, P., Rossi, C., Santoro, M., Dörr, A.J.M., Rizzoni, M., 2004. Comet assay and micronucleus test in circulating erythrocytes of Cyprinus carpio specimens exposed in situ to lake waters treated with disinfectants for potabilization. Mutation Research 557(2), 119-129.

Collins, A.R., Ma, A.G., Duthie, S.J., 1995. The kinetics of repair of oxidative DNA damage (strand breaks and oxidised pyrimidine) in human cells. Mutation Research 336(1), 6977.

Dusman, E., Luzza, M., Savegnago, L., lauxen, D., Vicentini, V.E.P., Tonial, I.V., Sauer, T.P., 2014. Allium серa L. as a bioindicator to measure cytotoxicity of surface water of the Quatorze River, located in Francisco Beltrão, Paraná, Brazil. Environmental Monitoring and Assessment 186(3), 1793-1800.

Eaton, A.D., Clesceri, L.S., Rice, E.W., Greenberg, A.E., 2005. Standard Methods for the Examination of Water and Wastewater. Centennial Edition, American Public Health Association, American Water Works association, Water Environment Federation, Washington DC.

Frenzilli, G., Nigro, M., Lyons, B.P., 2009. The Comet assay for the evaluation of genotoxic impact in aquatic environments. Mutation Research 681(1), 80-92.

Fuzinatto, C.F., Flohr, L., Melegari, S.P., Matias, W.G., 2013. Induction of micronucleus of Oreochromis niloticus exposed to waters from the Cubatão do Sul River, southern Brazil. Ecotoxicology and Environmental Safety 98, 103-109.

Heddle, J.A., Cimino, M.C., Hayashi, M., Romagna, F., Shelby, M.D., Tucker, J.D., Vanparys, P., MacGregor, J.J., 1991. Micronuclei as an index of cytogenic damage: past, present and future. Environmental Molecular Mutagenesis 18(4), 277-291. 
Hemachandra, C.K., Pathiratne, A., 2015. Assessing toxicity of copper, cadmium and chromium levels relevant to discharge limits of industrial effluents into inland surface waters using common onion, Allium cepa bioassay. Bulletin of Environmental Contamination and Toxicology 94(2), 199-203.

Hemachandra, C. K., Pathiratne, A., 2016. Combination of physico-chemical analysis, Allium cepa test system and Oreochromis niloticus erythrocyte based comet assay/nuclear abnormalities tests for cytogenotoxicity assessments of treated effluents discharged from textile industries. Ecotoxicology and Environmental Safety 131, 54-64.

Herrero, O., Martin, J.M.P., Freire, P.F., Lopez, L.C., Peropadre, A., Hazen, M.J., 2012. Toxicological evaluation of three contaminants of emerging concern by use of the Allium cepa test. Mutation Research 743(1-2), 20-24.

Hua, G., Reckhow, D. A., 2007. Comparison of disinfection byproduct formation from chlorine and alternative disinfectants. Water Research 41(8), 1667-678.

Illeperuma, O.A., 2000. Environmental pollution in Sri Lanka, Journal of National Science Foundation of Sri Lanka 28(4), 301-325.

Ippolito, J.A., Barbarick, K.A., Elliott, H.A., 2011. Drinking Water Treatment Residuals: A Review of Recent Uses. Journal of Environmental Quality 40(1), 1-12. doi:10.2134/jeq2010.0242

Kannangara, D.N.M., Pathiratne, A., 2015. Toxicity assessment of industrial wastewaters reaching Dandugan Oya, Sri Lanka using a plant based bioassay. Journal of National Science Foundation of Sri Lanka 43(2), 153-163.

Leme, D.M., Marin-Morales, M.A., 2009. Allium cepa test in environmental monitoring: A review on its application. Mutation Research 682(1), 71-81. 
Luo, Y., Guo, W., Ngo, H.H., Nghiem, L.D., Hai, F.I., Zhang, J., Liang, S., Wang, X.C., 2014. A review on the occurrence of micropollutants in the aquatic environment and their fate and removal during wastewater treatment. Science of the Total Environment 473-474, 619641.

Maffei, F., Carbone, F., Forti, G.C., Buschini A., Poli, P., Rossi, C., Marabini L., Radice, S., Chiesara, E., Hrelia P., 2009. Drinking water quality: An in vitro approach for the assessment of cytotoxic and genotoxic load in water sampled along distribution system. Environmental International 35(7), 1053-1061.

McKie, M.J., Andrews, S.A., Andrews, R.C., 2016. Conventional drinking water treatment and direct biofiltration for the removal of pharmaceuticals and artificial sweeteners: A pilotscale approach. Science of the Total Environment 544, 10-17.

Monarca, S. Feretti, D., Zani, C., Rizzoni, M., Casarella, S., Gustavino, B., 2005. Genotoxicity of drinking water disinfectants in plant bioassays. Environmental and Molecular Mutagenesis 46(2): 96-103.

Ohe, T., Watanabe, T., Wakabayashi, K., 2004. Mutagens in surface waters: a review. Mutation Research/Reviews in Mutation Research, 567(2-3), 109-149.

Osman, A.G.M., Abuel-Fadl, K.Y., Kloas, W., 2012. In situ evaluation of the genotoxic potential of the river Nile: II. Detection of DNA strand-breakage and apoptosis in Oreochromis niloticus niloticus (Linnaeus, 1758) and Clarias gariepinus (Burchell, 1822). Mutation Research 747(1), 14-21. 
Padhye, L.P., Yao, H., Kungu, F.T., Huang, C., 2014. Year-long evaluation on the occurrence and fate of pharmaceuticals, personal care products, and endocrine disrupting chemicals in an urban drinking water treatment plant. Water Research 51, 266-276.

Pathiratne, A., Hemachandra, C.K., De Silva, N., 2015. Efficacy of Allium cepa test system for screening cytotoxicity and genotoxicity of industrial effluents originated from different industrial activities. Environment Monitoring and Assessment 187, 730, 1-12. doi $10.1007 / \mathrm{s} 10661-015-4954-\mathrm{z}$

Richardson, S.D., Plewa, M.J., Wagner, E.D., Schoeny, R., DeMarini, D.M., 2007. Occurrence, genotoxicity, and carcinogenicity of regulated and emerging disinfection by-products in drinking water: A review and roadmap for research. Mutation Research 636(1-3), 178242.

Serrano, M., Montesinos, I., Cardador, M.J., Silva, M., Gallego, M., 2015. Seasonal evaluation of the presence of 46 disinfection by-products throughout a drinking water treatment plant, Science of the Total Environment 517, 246-258.

Shi, P., Ma, R., Zhou, Q., Li, A., Wu, B., Miao, Y., Chen, X., Zhang, X., 2015. Chemical and bioanalytical assessments on drinking water treatments by quaternized magnetic microspheres, Journal of Hazardous Materials 285, 53-60.

SLSI (Sri Lanka Standards Institution) 1985. Tolerance Limits for Inland Surface Waters for Use as Raw Water for Public Water Supply, SLS 722: 1985.

SLSI (Sri Lanka Standards Institution), 2013. Sri Lanka Standards for potable water - SLS 614: 2013, Drinking water standard - First revision. 
Vujošević, M., Anđelković, S., Savić, G., Blagojević, J., 2008. Genotoxicity screening of the river Rasina in Serbia using the Allium anaphase-telophase test. Environmental Monitoring and Assessment 147(1), 75-81.

WHO, 2011. WHO guidelines for drinking water quality, 4th edition, World Health

Organization, Geneva, Switzerland. (Accessed 10th April 2016)

http://www.who.int/water_sanitation_health/publications/2011/dwq_guidelines/en/

Zar, J.H., 1999. Biostatistical Analysis. Fourth edition, Prentice Hall, Upper Saddle River New Jersey, USA.

Žegura, B., Heath, E., Černoša, A., Filipič M., 2009. Combination of in vitro bioassays for the determination of cytotoxic and genotoxic potential of wastewater, surface water and drinking water samples. Chemosphere 75, 453-1460.

Zeng, Q., Zhang, S., Liao, J., Miao, D., Wang, X., Yang, P., Yun, L., Liu, A., Lu, W., 2015. Evaluation of genotoxic effects caused by extracts of chlorinated drinking water using a combination of three different bioassays. Journal of Hazardous Materials 296, 23-29. 
Table 1 Measured physico-chemical parameters of raw water and effluent samples from the two drinking water treatment plants (DWTP 1 and DWTP 2). 


\begin{tabular}{|c|c|c|c|c|c|c|c|c|c|c|c|c|c|c|}
\hline Sample & 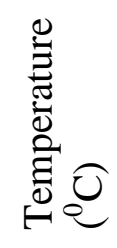 & $\frac{\pi}{2}$ & 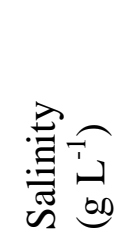 & 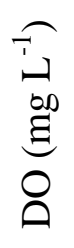 & 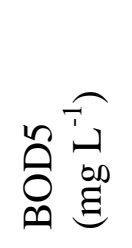 & ชิ & 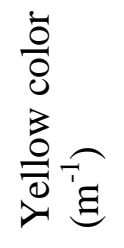 & 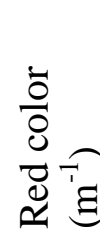 & 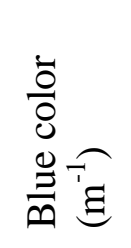 & శֹَ & 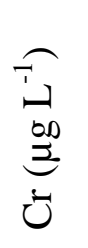 & 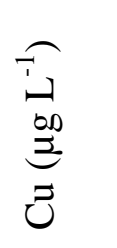 & 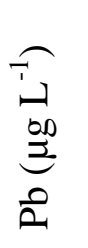 & 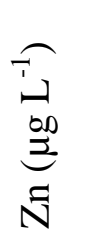 \\
\hline \multicolumn{15}{|l|}{ DWTP 1} \\
\hline (Wet period 1) Raw water & 27.4 & 5.5 & 0.03 & 6.4 & 4 & $<3$ & 0 & 0 & 0 & 2 & 1 & $<5$ & $<5$ & $<105$ \\
\hline Effluent & 26.6 & 6.1 & 0.04 & 6.8 & 20 & 120 & 8 & 6 & 4 & 2 & 10 & 105 & 10 & 150 \\
\hline Aged tap water & 27.1 & 6.9 & 0.02 & 6.2 & 1 & $<3$ & 0 & 0 & 0 & $<1$ & $<1$ & $<5$ & $<5$ & $<105$ \\
\hline (Dry period) Raw water & 27.4 & 6.7 & 0.02 & 5.8 & 7 & 32 & 0 & 0 & 0 & 3 & 1 & $<5$ & $<5$ & $<105$ \\
\hline Effluent & 27.6 & 5.7 & 0.21 & 7.6 & 13 & 100 & 5 & 2 & 1 & 3 & 34 & 140 & 95 & 146 \\
\hline Aged tap water & 28.1 & 7.1 & 0.02 & 7.2 & 2 & 3 & 0 & 0 & 0 & $<1$ & $<1$ & $<5$ & $<5$ & $<105$ \\
\hline (Wet period 2) Raw water & 26.1 & 6.2 & 0.02 & 8.0 & 5 & 25 & 1 & 1 & 0 & $<1$ & 1 & $<5$ & $<5$ & $<105$ \\
\hline Effluent & 26.2 & 7.0 & 0.23 & 9.1 & 11 & 90 & 2 & 2 & 2 & 8 & 26 & 78 & 100 & 133 \\
\hline Aged tap water & 27.3 & 6.9 & 0.02 & 6.5 & 1 & 3 & 0 & 0 & 0 & $<1$ & $<1$ & $<5$ & $<5$ & $<105$ \\
\hline \multicolumn{15}{|l|}{ DWTP 2} \\
\hline (Wet period 1) Raw water & 26.5 & 7.7 & 0.02 & 5.2 & 4 & 31 & 0 & 0 & 0 & 21 & 2 & $<5$ & $<5$ & 113 \\
\hline Effluent & 27.2 & 8.2 & 0.20 & 4.4 & 20 & 150 & 5 & 2 & 1 & 3 & 30 & 78 & $<5$ & 157 \\
\hline Aged tap water & 27.4 & 7.1 & 0.02 & 6.1 & 2 & 4 & 0 & 0 & 0 & $<1$ & $<1$ & $<5$ & $<5$ & $<105$ \\
\hline (Dry period) Raw water & 28.4 & 5.9 & 0.03 & 6.2 & 7 & 42 & 2 & 1 & 1 & 3 & 1 & $<5$ & $<5$ & $<105$ \\
\hline Effluent & 29.4 & 6.4 & 0.11 & 7.1 & 7 & 90 & 3 & 2 & 1 & 1 & 60 & 13 & $<5$ & $<105$ \\
\hline Aged tap water & 27.4 & 6.9 & 0.02 & 6.9 & 2 & 5 & 0 & 0 & 0 & $<1$ & $<1$ & $<5$ & $<5$ & $<105$ \\
\hline (Wet period 2) Raw water & 25.3 & 6.8 & 0.20 & 6.8 & 7 & 22 & 3 & 2 & 1 & $<1$ & 23 & $<5$ & $<5$ & $<105$ \\
\hline Effluent & 26.3 & 8.1 & 0.24 & 7.6 & 5 & 126 & 5 & 3 & 2 & 8 & 205 & 52 & 26 & 125 \\
\hline Aged tap water & 27.6 & 7.2 & 0.02 & 6.2 & 2 & 4 & 0 & 0 & 0 & $<1$ & $<1$ & $<5$ & $<5$ & $<105$ \\
\hline $\begin{array}{l}\text { *Tolerance limits for intake } \\
\text { source water }\end{array}$ & - & $6-9$ & - & 4 & 5 & - & - & - & - & - & 50 & - & 100 & - \\
\hline $\begin{array}{l}* * \text { Tolerance limits for } \\
\text { effluent discharge }\end{array}$ & 40 & $6-8.5$ & - & - & 30 & 250 & 7 & 5 & 3 & 100 & 500 & 3000 & 100 & 200 \\
\hline
\end{tabular}


The LOQ for $\mathrm{Cd}, \mathrm{Cr}, \mathrm{Cu}, \mathrm{Pb}$ and $\mathrm{Zn}\left(\right.$ in $\mu \mathrm{g} \mathrm{L}^{-1}$ ) are 1, 1, 5, 5 and 105 respectively. * (SLS, 1985), ** (Anonymous, 2008). 
Table 2. Measured physico-chemical characteristics of water samples from different treatment steps of the two drinking water treatment plants (DWTP 1 and DWTP 2) and the portable drinking water (control)

\begin{tabular}{|c|c|c|c|c|c|c|c|c|c|c|c|}
\hline Sample & 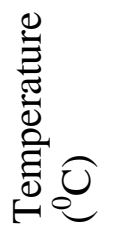 & $\frac{\pi}{2}$ & 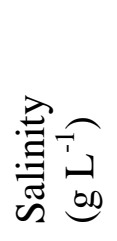 & 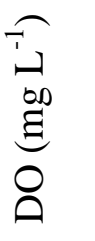 & مُ & 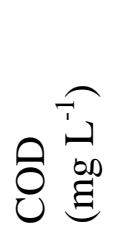 & 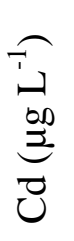 & 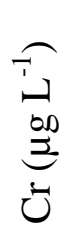 & 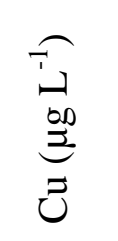 & 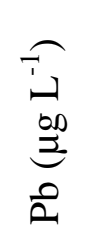 & 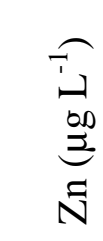 \\
\hline \multicolumn{12}{|l|}{ DWTP 1} \\
\hline Raw water & 29.1 & 7.0 & 0.02 & 6.9 & 3 & 20 & 0 & $<1$ & $<3$ & $<1$ & $<120$ \\
\hline Filtered water & 29.8 & 7.1 & 0.02 & 7.8 & 1 & 10 & 0 & $<1$ & $<3$ & $<1$ & $<120$ \\
\hline Chlorinated water & 28.2 & 7.5 & 0.03 & 8.1 & 1 & 7 & 0 & $<1$ & $<3$ & $<1$ & $<120$ \\
\hline Distribution water & 29.0 & 7.7 & 0.02 & 7.6 & 1 & 3 & 0 & $<1$ & $<3$ & $<1$ & $<120$ \\
\hline Portable drinking water(control) & 28.1 & 6.9 & 0.02 & 6.9 & 1 & 3 & 0 & $<1$ & $<3$ & $<1$ & $<120$ \\
\hline \multicolumn{12}{|l|}{ DWTP 2} \\
\hline Raw water & 28.4 & 7.3 & 0.03 & 6.9 & 5 & 18 & 0 & $<1$ & $<3$ & $<1$ & $<120$ \\
\hline Filtered water & 27.9 & 6.8 & 0.03 & 7.0 & 2 & 9 & 0 & $<1$ & $<3$ & $<1$ & $<120$ \\
\hline Chlorinated water & 28.3 & 7.7 & 0.03 & 7.5 & 2 & 5 & 0 & $<1$ & $<3$ & $<1$ & $<120$ \\
\hline Distribution water & 28.4 & 6.8 & 0.04 & 4.8 & 2 & 5 & 0 & $<1$ & $<3$ & $<1$ & $<120$ \\
\hline Portable drinking water(control) & 28.2 & 6.6 & 0.03 & 4.3 & 2 & 6 & 0 & $<1$ & $<3$ & $<1$ & $<120$ \\
\hline $\begin{array}{l}\text { *National tolerance limits for } \\
\text { intake source water }\end{array}$ & - & $6-9$ & - & 4 & 5 & - & - & 50 & - & 100 & - \\
\hline $\begin{array}{l}* * \text { National guidelines for } \\
\text { drinking water quality }\end{array}$ & - & $6.5-8.5$ & - & - & - & 10 & 3 & 50 & 1000 & 10 & 3000 \\
\hline $\begin{array}{l}* * * \text { WHO guidelines for } \\
\text { drinking water quality }\end{array}$ & - & $6.5-8.5$ & - & - & - & - & 3 & 50 & 2000 & 10 & - \\
\hline
\end{tabular}


Table 3. Responses of A. cepa bulbs exposed to water samples from different treatment steps of

\begin{tabular}{lccccc}
\hline Exposure & $\begin{array}{c}\text { Mitotic } \\
\text { Index (\%) }\end{array}$ & $\begin{array}{c}\text { Chromosomal } \\
\text { abnormalities } \\
(\%)\end{array}$ & $\begin{array}{c}\text { Cells with } \\
\text { micronuclei } \\
(\%)\end{array}$ & $\begin{array}{c}\text { Cells with } \\
\text { nuclear } \\
\text { buds (\%) }\end{array}$ & $\begin{array}{c}\text { Root } \\
\text { growth } \\
(\mathrm{cm})\end{array}$ \\
\hline DWTP 1 & & & & & \\
Raw water & $26.7 \pm 0.5^{\mathrm{b}}$ & $11.3 \pm 0.9^{\mathrm{b}}$ & $0.2 \pm 0.2^{\mathrm{a}}$ & $0.4 \pm 0.4^{\mathrm{a}}$ & $9.8 \pm 0.1^{\mathrm{c}}$ \\
Filtered water & $27.5 \pm 0.5^{\mathrm{ab}}$ & $16.8 \pm 1.4^{\mathrm{bc}}$ & $0.2 \pm 0.2^{\mathrm{a}}$ & $0 \pm 0^{\mathrm{a}}$ & $11.4 \pm 0.1^{\mathrm{b}}$ \\
Chlorinated water & $30.8 \pm 1.4^{\mathrm{ab}}$ & $17.2 \pm 0.7^{\mathrm{c}}$ & $0 \pm 0^{\mathrm{a}}$ & $0.2 \pm 0.2^{\mathrm{a}}$ & $13.9 \pm 0.1^{\mathrm{a}}$ \\
Distribution water & $32.7 \pm 1.4^{\mathrm{a}}$ & $15.4 \pm 1.0^{\mathrm{bc}}$ & $0 \pm 0^{\mathrm{a}}$ & $0 \pm 0^{\mathrm{a}}$ & $14.1 \pm 0.2^{\mathrm{a}}$ \\
*Portable drinking & $38.2 \pm 1.6^{\mathrm{a}}$ & $4.3 \pm 1.1^{\mathrm{a}}$ & $0 \pm 0^{\mathrm{a}}$ & $0 \pm 0^{\mathrm{a}}$ & $14.4 \pm 0.1^{\mathrm{a}}$ \\
water & & & & &
\end{tabular}

\section{DWTP 2}

Raw water

$$
29.2 \pm 1.7^{\mathrm{b}}
$$

$10.8 \pm 0.7^{\mathrm{b}}$

$0.2 \pm 0.2^{\mathrm{a}}$

$0.8 \pm 0.5^{\mathrm{a}}$

$12.2 \pm 0.2^{\mathrm{b}}$

Filtered water

$$
29.7 \pm 0.8^{\mathrm{b}}
$$

$12.3 \pm 1.2^{\mathrm{bc}}$

$0.2 \pm 0.2^{\mathrm{a}}$

$0 \pm 0^{\mathrm{a}}$

$13.0 \pm 0.3^{\mathrm{b}}$

Chlorinated water

$34.1 \pm 2.4^{\mathrm{ab}}$

$15.9 \pm 0.6^{\mathrm{c}}$

$0 \pm 0^{\mathrm{a}}$

$0.4 \pm 0.2^{\mathrm{a}}$

$14.2 \pm 0.3^{\mathrm{a}}$

Distribution water

$$
34.8 \pm 1.0^{\mathrm{ab}}
$$

$14.3 \pm 0.8^{\mathrm{bc}}$

$0 \pm 0^{\mathrm{a}}$

$0 \pm 0^{\mathrm{a}}$

$13.4 \pm 0.1^{\mathrm{ab}}$

*Portable drinking

$36.0 \pm 1.1^{\mathrm{a}}$

$2.7 \pm 1.2^{\mathrm{a}}$

$0 \pm 0^{\mathrm{a}}$

$0 \pm 0^{\mathrm{a}}$

$14.6 \pm 0.3^{\mathrm{a}}$

water

**EMS $10 \mathrm{mg} \mathrm{L}^{-1}$

$28.2 \pm 3.64^{\mathrm{b}}$

$21.7 \pm 2.8^{\mathrm{c}}$

$3.4 \pm 0.8^{\mathrm{b}}$

$5.2 \pm 2.4^{\mathrm{b}}$

Not done

the drinking water treatment plants (DWTP1 and DWTP 2)

Data are presented as mean \pm SEM $(n=5)$. For a specific DWTP, data in a column with different superscript letters indicate significant difference from each other at $\mathrm{P}<0.05$. *negative control, **positive control 
Table 4. Response of erythrocytes of $O$. niloticus exposed to water samples from different treatment steps of the drinking water treatment plants (DWTP 1 and DWTP 2)

\begin{tabular}{lccc}
\hline Exposure & Micronuclei (\%) & Nuclear buds (\%) & Total Comet scor \\
\hline DWTP 1 & & & \\
Raw water & $4.0 \pm 0.9^{\mathrm{b}}$ & $7.2 \pm 1.9^{\mathrm{b}}$ & $94 \pm 6^{\mathrm{c}}$ \\
Filtered water & $0.8 \pm 0.4^{\mathrm{a}}$ & $3.2 \pm 0.9^{\mathrm{ab}}$ & $80 \pm 5^{\mathrm{c}}$ \\
Chlorinated water & $0.6 \pm 0.4^{\mathrm{a}}$ & $3.0 \pm 0.5^{\mathrm{ab}}$ & $49 \pm 7^{\mathrm{b}}$ \\
Distribution water & $0.6 \pm 0.6^{\mathrm{a}}$ & $2.2 \pm 0.9^{\mathrm{a}}$ & $17 \pm 5^{\mathrm{a}}$ \\
*Portable drinking water & $0.2 \pm 0.2^{\mathrm{a}}$ & $0.3 \pm 0.3^{\mathrm{a}}$ & $14 \pm 3^{\mathrm{a}}$ \\
& & & \\
DWTP 2 & & & \\
Raw water & $3.6 \pm 0.4^{\mathrm{b}}$ & $6.2 \pm 2.2^{\mathrm{b}}$ & $68 \pm 4^{\mathrm{b}}$ \\
Filtered water & $0 \pm 0^{\mathrm{a}}$ & $2.2 \pm 0.9^{\mathrm{a}}$ & $46 \pm 3^{\mathrm{b}}$ \\
Chlorinated water & $3.2 \pm 0.5^{\mathrm{b}}$ & $7.0 \pm 3.7^{\mathrm{b}}$ & $50 \pm 2^{\mathrm{b}}$ \\
Distribution water & $0.8 \pm 0.4^{\mathrm{a}}$ & $0.6 \pm 0.6^{\mathrm{a}}$ & $13 \pm 4^{\mathrm{a}}$ \\
$*$ Portable drinking water & $0 \pm 0^{\mathrm{a}}$ & $0 \pm 0^{\mathrm{a}}$ & $6 \pm 2^{\mathrm{a}}$ \\
$* * \mathrm{~K}_{2} \mathrm{Cr}_{2} \mathrm{O}_{7} 2.5$ mg L ${ }^{-1}$ & $5.1 \pm 2.9^{\mathrm{b}}$ & $7.6 \pm 1.4^{\mathrm{b}}$ & $168 \pm 9^{\mathrm{c}}$ \\
\hline
\end{tabular}

Data are presented as mean \pm SEM $(n=5)$. For a specific DWTP, data in a column with different superscript letters indicate significant difference from each other at $\mathrm{P}<0.05$. *negative control, **positive control 
(a) Mitotic Index

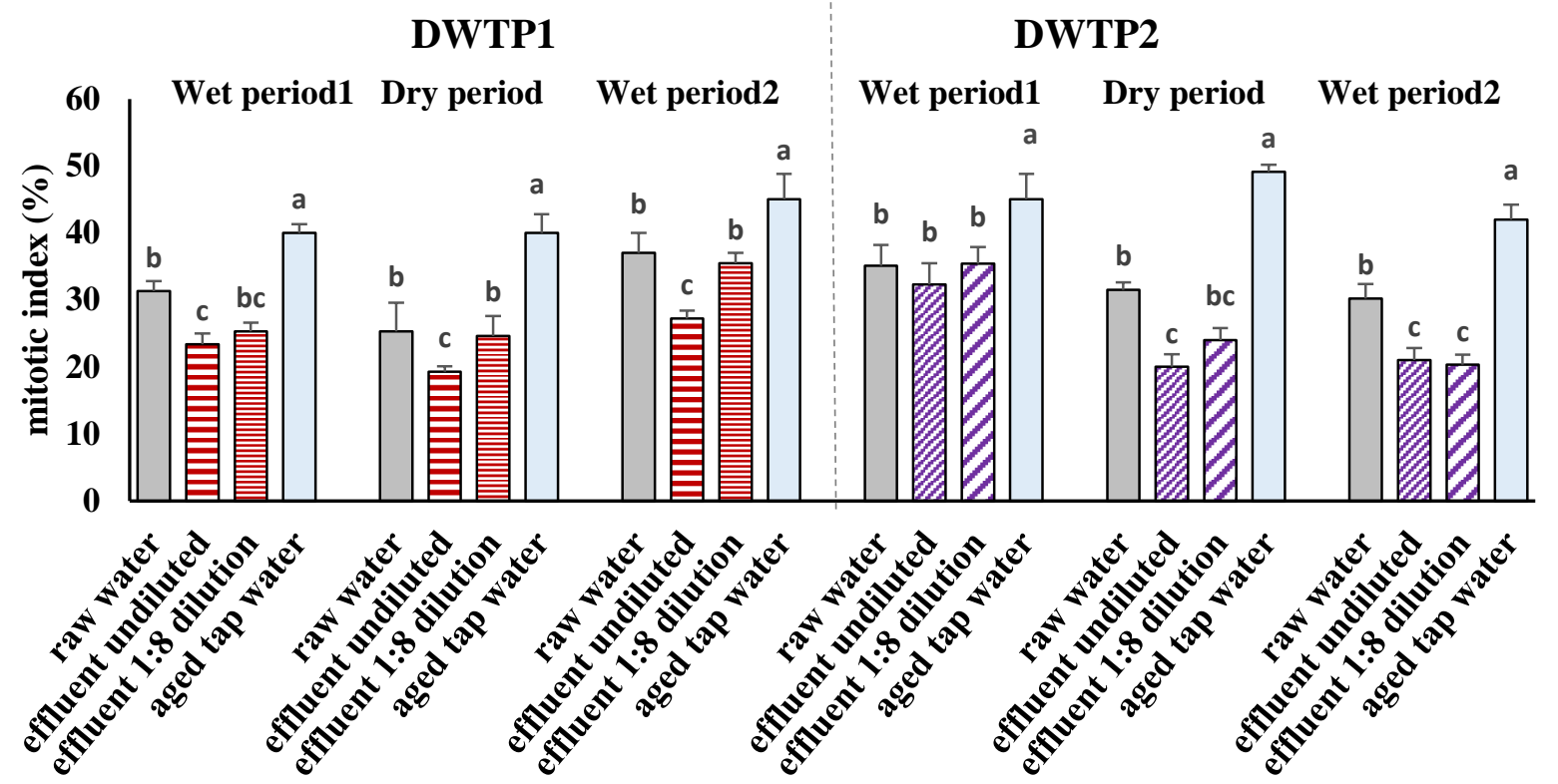

(b) Root growth

\section{\begin{tabular}{l|r} 
DWTP1 & DWTP2
\end{tabular}}

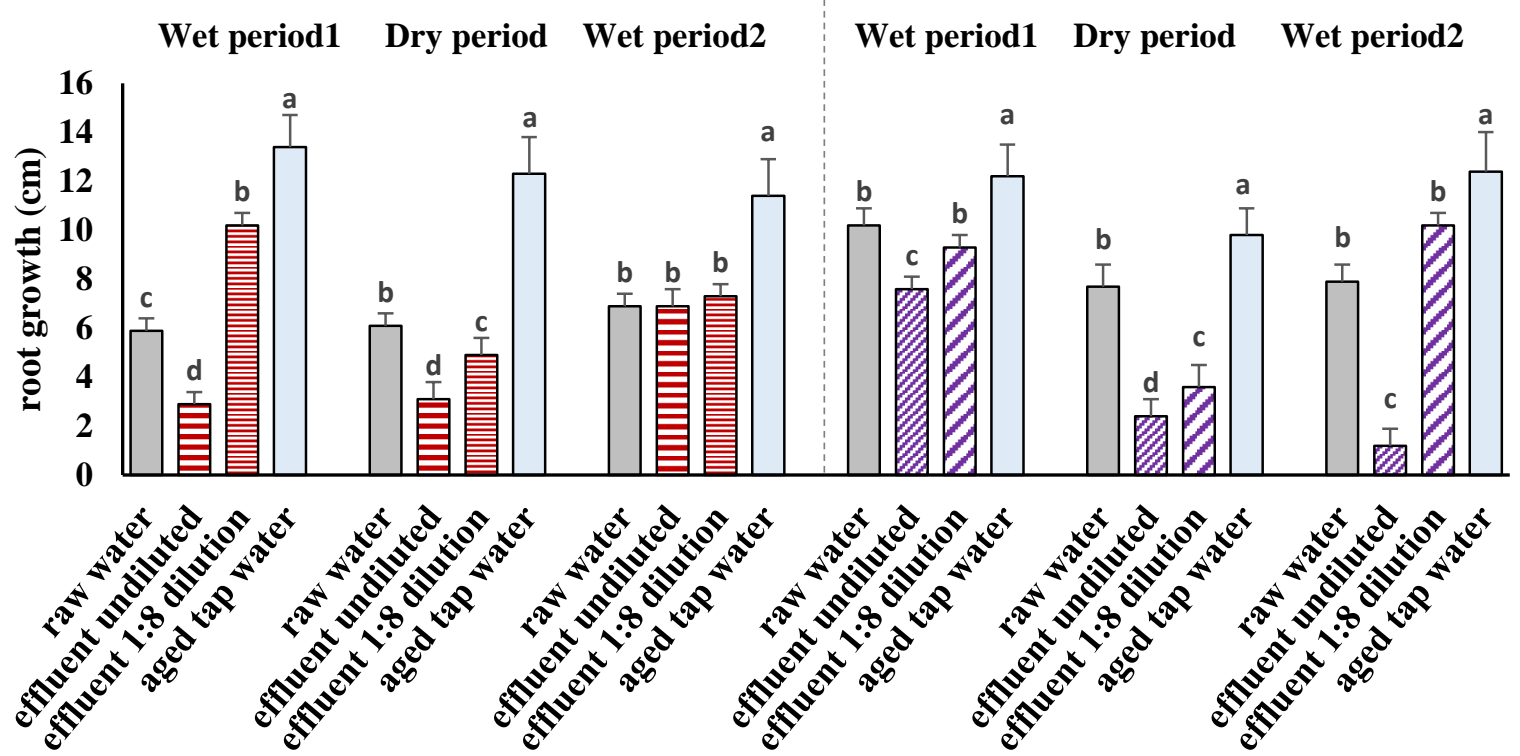

Fig. 1. Mitotic indices and root growth of A. cepa bulbs exposed to raw water and effluents of two drinking water treatment plants (DWTP1 and DWTP2). Data in columns are presented as mean \pm SEM $(n=5)$. For a specific sampling period, the columns with different letters indicate significant differences from each other at $\mathrm{P}<0.05$. 
DWTP1

DWTP2

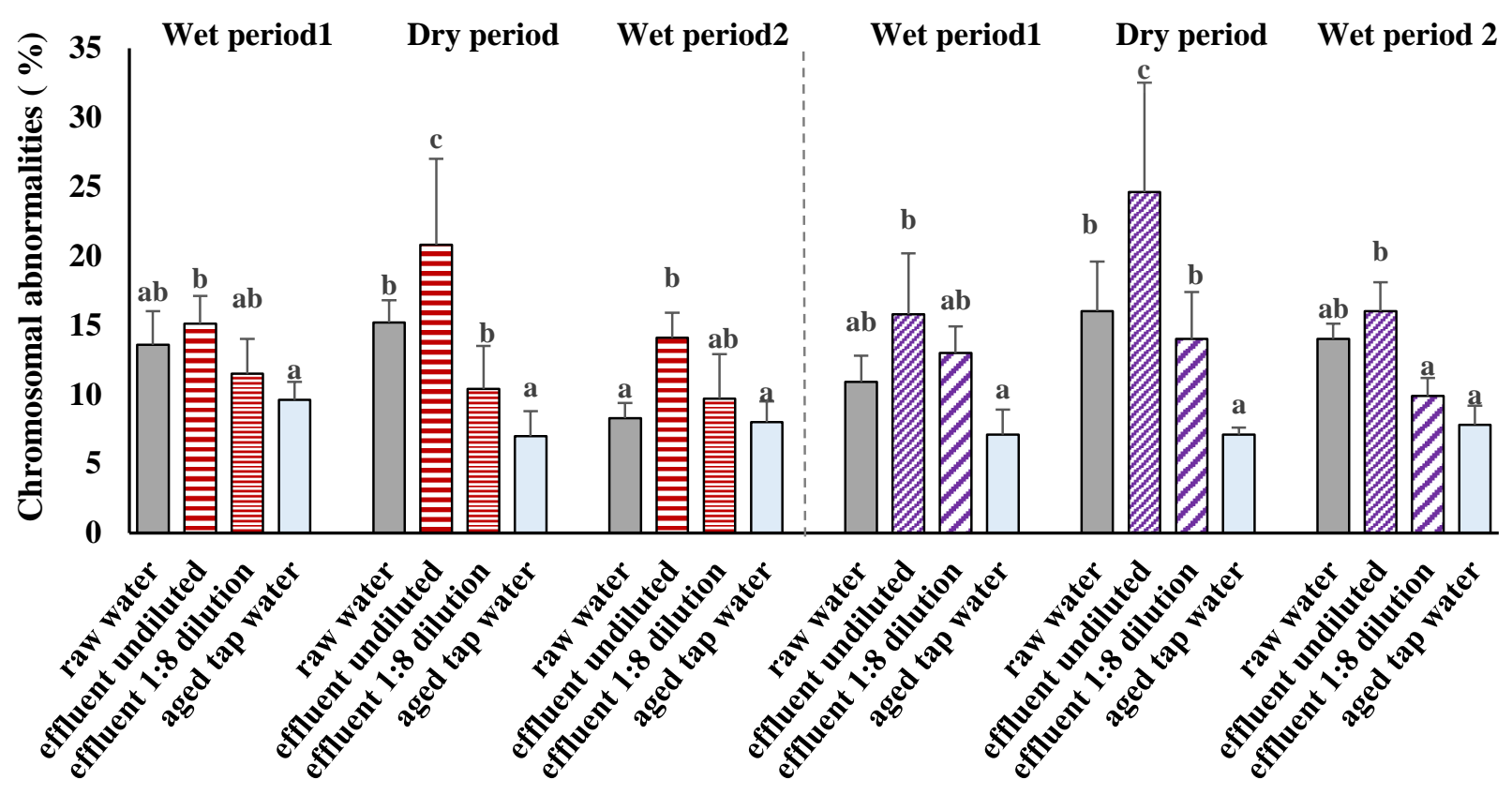

Fig. 2. Chromosomal abnormalities in A. cepa bulbs exposed to raw water and effluents of two drinking water treatment plants (DWTP1 and DWTP2). Data in columns are presented as mean \pm SEM $(n=5)$. For a specific sampling period, the columns with different letters indicate significant differences from each other at $\mathrm{P}<0.05$. 
(a) Micronucleated cells

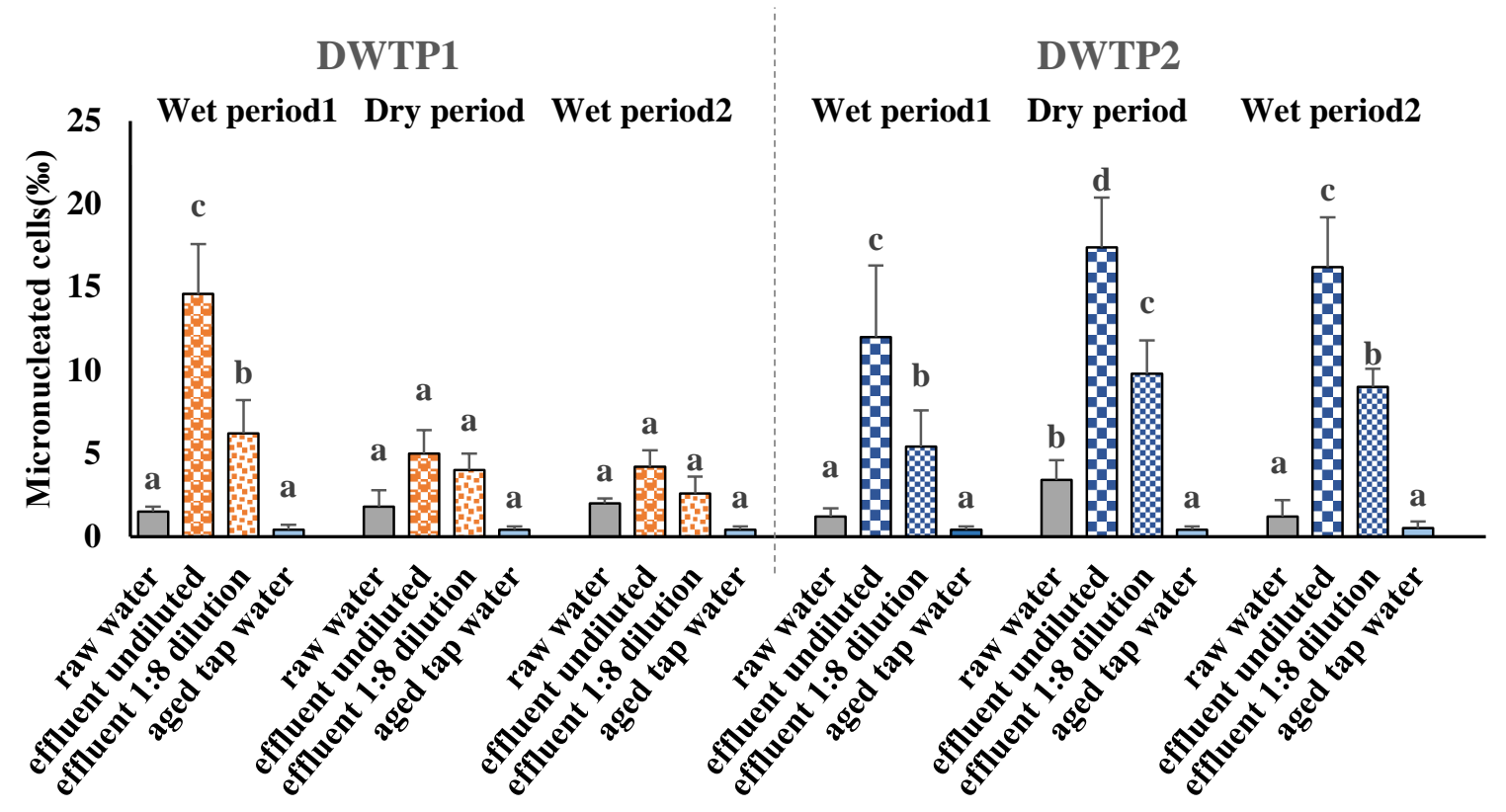

(b) Cells with nuclear buds

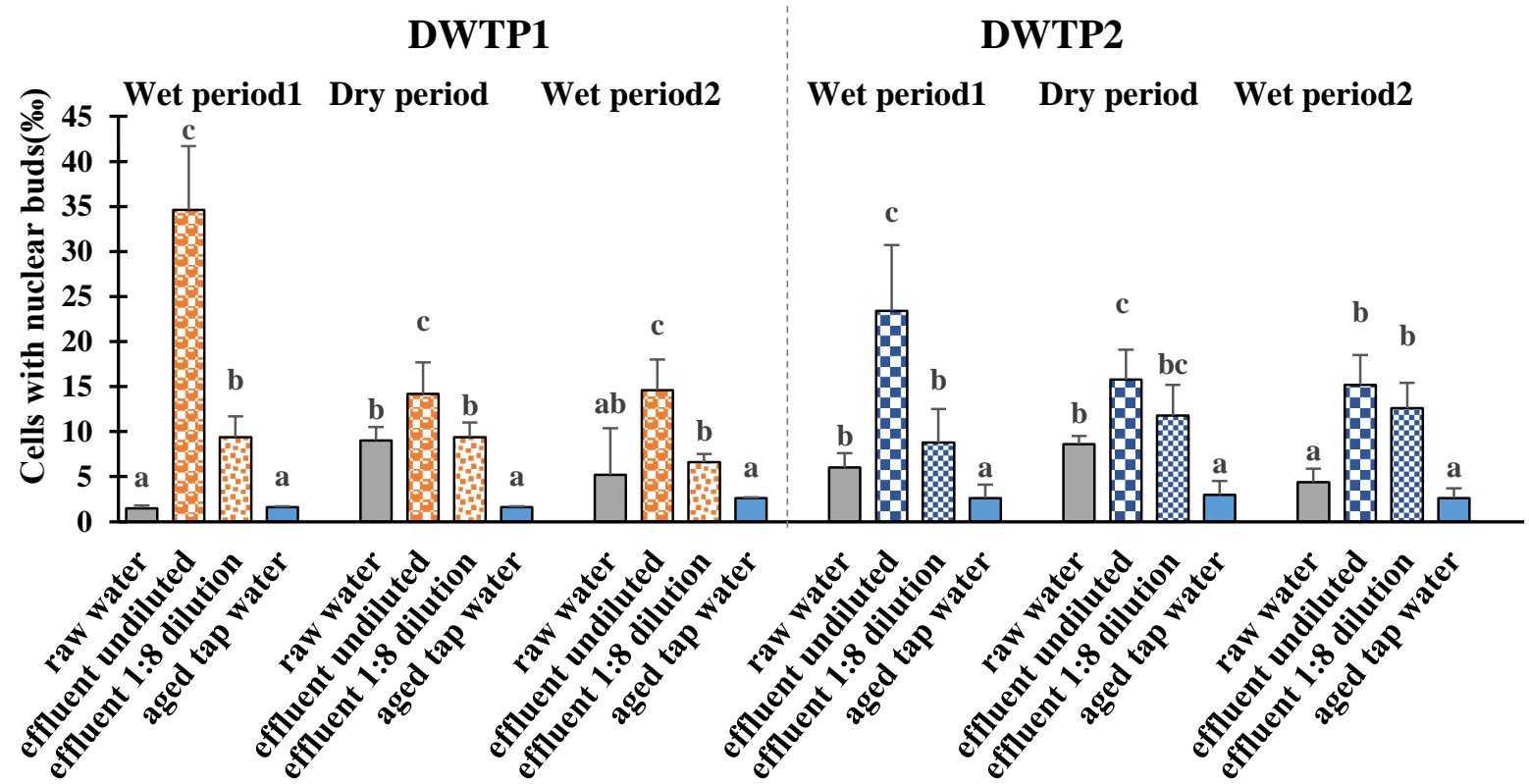

Fig. 3. Occurrence of micronuclei and nuclear buds in $O$. niloticus erythrocytes exposed to raw water and effluents of two drinking water treatment plants (DWTP1 and DWTP2). Data in columns are presented as mean \pm SEM $(n=5)$. For a specific sampling period, the data with different letters indicate significant difference from each other at $\mathrm{P}<0.05$. 


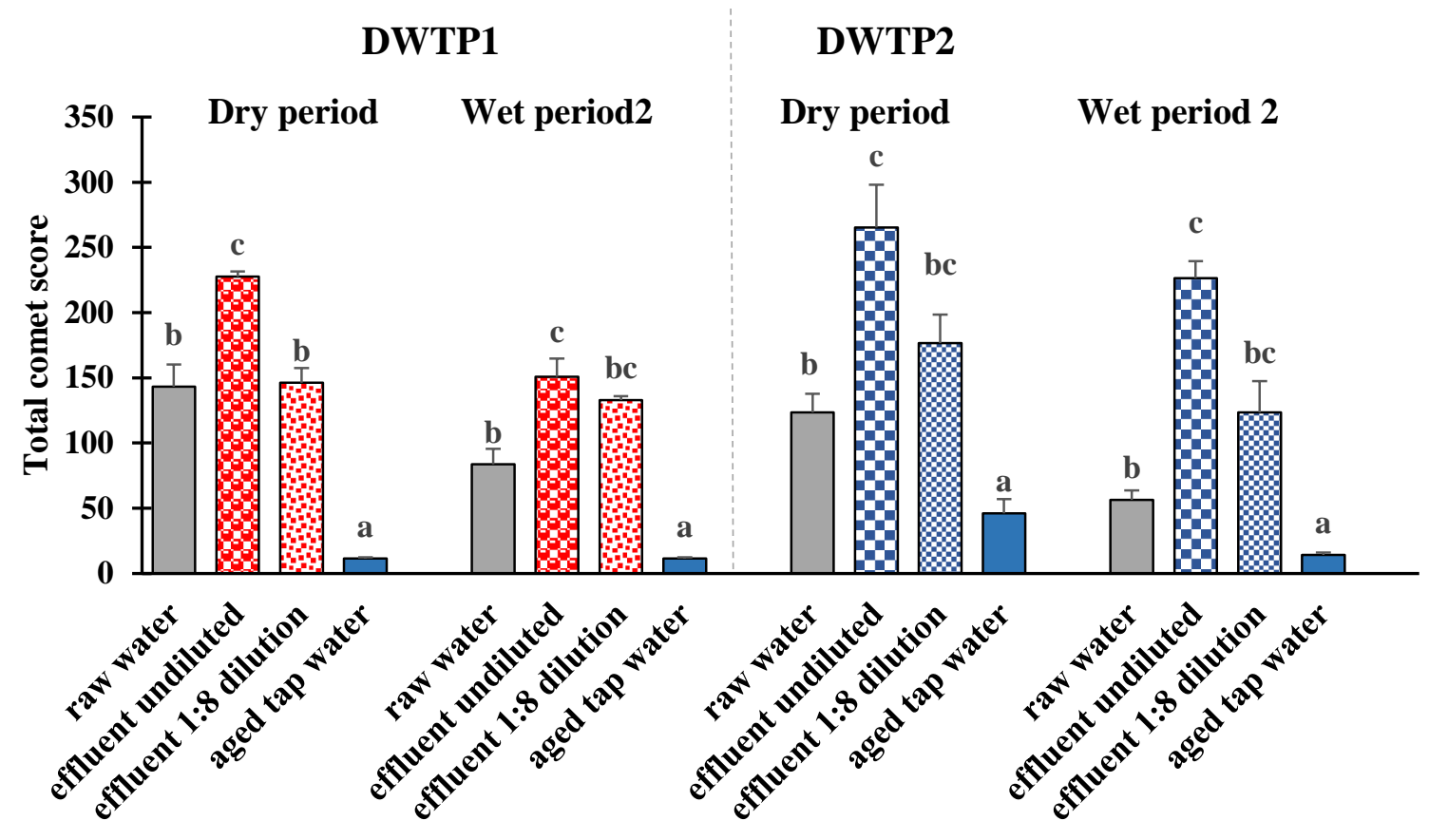

Fig. 4. Total comet scores relevant to $O$. niloticus erythrocytes exposed to raw water and effluents of two drinking water treatment plants (DWTP1 and DWTP2). Data in columns are presented as mean \pm SEM $(n=5)$. For a specific sampling period, the data with different letters indicate significant difference from each other at $\mathrm{P}<0.05$. Data not available for the wet period 1 . 
Graphical abstract

In vivo Bioassays for Cytogenotoxicity Screening of Source Water and Treated Water

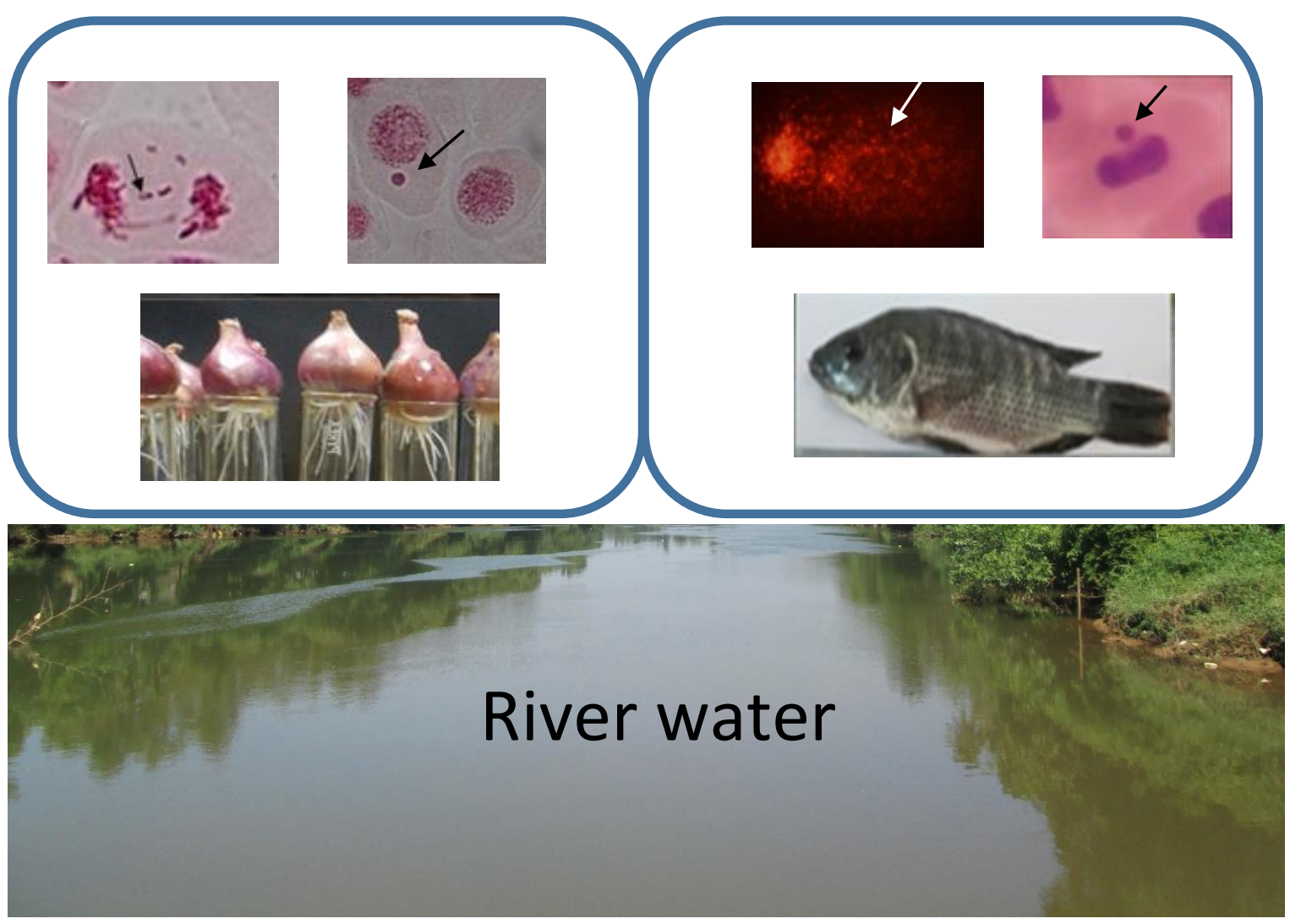

